\title{
KARAKTERISTIK DAN AKTIVITAS ANTIBAKTERI YOGHURT SARI BUAH SIRSAK (Annona muricata L.) TERHADAP BAKTERI FLORA USUS
}

\author{
Jumiati Catur Ningtyas*, Adam M. Ramadhan, Laode Rijai \\ Laboratorium Penelitian dan Pengembangan "FARMAKA TROPIS" Fakultas \\ Farmasi Universitas Mulawarman, Samarinda, Kalimantan Timur \\ Email: jumiaticningtyas@gmail.com
}

\begin{abstract}
ABSTRAK
Yoghurt adalah produk hasil fermentasi yang mengandung asam laktat, dan bakteriosin yang dapat menekan pertumbuhan bakteri patogen dalam usus. Sirsak (Annona muricata L.) mengandung vitamin C, gula, dan protein yang memberikan energi bagi proses metabolisme bakteri asam laktat dalam yoghurt sehingga meningkatkan jumlah bakteri asam laktat dan menghasilkan lebih banyak senyawa antibakteri. Penelitian ini dilakukan untuk mengetahui total BAL, $\mathrm{pH}$, dan aktivitas antibakteri dari yoghurt sari buah sirsak terhadap bakteri Escherichia coli dan Shigella dysenteriae. Pengujian total BAL dilakukan dengan menggunakan metode hitung cawan (Total Plate Count) dalam medium MRSA (Man Ragosa Shapre Agar). Pengujian aktivitas antibakteri dari yoghurt sari buah sirsak dilakukan dengan metode sumuran (well diffusion). Hasil total BAL yoghurt sari buah sirsak pada konsentrasi $0 \%\left(38 \times 10^{9}\right), 15 \%\left(10 \times 10^{9}\right), 20 \%\left(18 \times 10^{9}\right), 25 \%\left(45 \times 10^{9}\right)$, $50 \%\left(22 \times 10^{9}\right)$, , dan $75 \%\left(17 \times 10^{9}\right)$. Nilai $\mathrm{pH}$ dari yoghurt sari buah sirsak berkisar antara 4-5. Hasil pengujian antibakteri terhadap bakteri Escherichia coli menunjukkan zona bening $0 \%(0 \mathrm{~mm}), 15 \%(5,51 \mathrm{~mm}), 20 \%(6,63 \mathrm{~mm}), 25 \%$ $(7,23 \mathrm{~mm}), 50 \%(7,64 \mathrm{~mm})$, dan $75 \%(7,16 \mathrm{~mm})$. Hasil pengujian antibakteri terhadap bakteri Shigella dysenteriae menunjukkan zona bening $0 \%(0 \mathrm{~mm}), 15 \%$ (4,05 mm), $20 \%$ (4,56 mm), $25 \%$ (4,74 mm), $50 \%$ (4,91 mm), dan 75\% (5,39 $\mathrm{mm})$. Berdasarkan total BAL, $\mathrm{pH}$ dan aktivitas antibakteri, yoghurt dengan penambahan sari buah sirsak yang paling baik adalah pada konsentrasi $25 \%$.
\end{abstract}

Kata Kunci : Annona muricata L., Yoghurt, Bakteri Asam Laktat, Antibakteri

\section{PENDAHULUAN}

Yoghurt adalah produk susu yang difermentasi oleh bakteri. Bakteri yang biasa digunakan yaitu Lactobacillus bulgaricus dan Streptococcus thermophilus. Kedua bakteri tersebut merupakan bakteri gram positif yang biasa disebut sebagai bakteri asam laktat karena dapat memfermentasi laktosa pada susu menjadi asam laktat. Asam laktat yang dihasilkan dari fermentasi tersebut menciptakan flavor 
yoghurt yang khas, dengan cita rasa asam dan tekstur kental akibat koagulasi protein susu oleh asam.

Buah sirsak (Annona muricata L.) merupakan buah tropis yang banyak digemari di Indonesia selain rasanya yang enak, buah sirsak dikenal memiliki banyak manfaat bagi kesehatan, antara lain sebagai penumpas kanker, mengobati asam urat, dan anti sembelit. Selain itu, buah sirsak juga berfungsi sebagai antibakteri. Buah sirsak yang sudah matang terasa lebih asam karena mengandung vitamin $\mathrm{C}$, selain itu sirsak juga mengandung protein, kalsium, fosfor dan vitamin A (Octavia, 2003). Buah sirsak (Annona muricata L.) mempunyai aktivitas antibakteri dan dapat menghambat pertumbuhan bakteri dari golongan gram negatif (Octavia, 2003). Buah sirsak memiliki kandungan karbohidrat yang banyak yaitu sebanyak 16,30 gram dalam 100 gram daging buahnya (Mardiana, 2012).

Bakteri asam laktat Lactobacillus bulgaricus dan Streptococcus thermophilus yang berperan dalam fermentasi yoghurt membutuhkan nutrisi yang kompleks agar dapat mengubah laktosa dalam susu menjadi asam laktat. Oleh karena itu, karbohidrat yang banyak terkandung dalam buah sirsak kemungkinan dapat menjadi sumber nutrisi bagi BAL dalam pembuatan yoghurt sehingga diperoleh total bakteri asam laktat yang banyak yang mana akan menghasilkan banyak asam laktat.

Selain sebagai sumber nutrisi, buah sirsak yang memiliki rasa yang enak juga dapat menambah cita rasa dalam yoghurt. Banyaknya asam laktat yang dihasilkan oleh BAL akan sangat berpengaruh dalam aktivitas antibakterinya. Maka dari itu, penulis tertarik melakukan penelitian tentang aktivitas antibakteri yoghurt sari buah sirsak.

\section{METODE PENELITIAN}

\section{Bahan}

Bahan yang digunakan dalam penelitian ini adalah susu sapi pasteurisasi, buah sirsak (Annona muricata L.) yang didapatkan dari Pasar Buah Segiri Kota Samarinda, Susu Skim bubuk, gula pasir, dan aquades. Medium yang digunakan 
dalam penelitian ini adalah medium Nutrient Agar dan medium MRSA (deMann Ragosa Sharpe Agar).

\section{Alat}

Peralatan yang digunakan dalam penelitian ini adalah timbangan analitik, autoklaf, inkubator, cawan petri, erlenmeyer, gelas kimia, spoit injeksi, hot plate, Laminar Air Flow, blender, colony counter, mikrometer sekrup, mikropipet, tip, pH meter, pencadang besi dan alat penunjang lainnya.

\section{Prosedur Penelitian}

\section{Penyiapan sari buah sirsak}

Sampel yang berupa buah sirsak segar dan matang di pilih dan dikupas, kemudian dihaluskan menggunakan blender. Kemudian disaring sehingga diperoleh sari buah.

\section{Pembuatan starter yoghurt}

Disiapkan dua buah gelas kimia berisi susu sapi pasteurisasi sebanyak masingmasing $100 \mathrm{~mL}$, dipanaskan hingga suhu $72{ }^{\circ} \mathrm{C}$ selama 15 menit. Susu didinginkan hingga mencapai suhu $43{ }^{\circ} \mathrm{C}$. Kemudian dimasukkan suspensi bakteri Lactobacillus bulgaricus dan Streptococcus thermophilus sebanyak 3\% ke dalam masing masing gelas kimia yang telah berisi $100 \mathrm{~mL}$ susu sapi yang bersuhu $43{ }^{\circ} \mathrm{C}$.

\section{Pembuatan yoghurt sari buah sirsak}

Susu sapi pasteurisasi sebanyak $50 \mathrm{ml}$ dipasteurisasi selama 15 menit dengan suhu $75{ }^{\circ} \mathrm{C}$, didinginkan hingga mencapai suhu $43{ }^{\circ} \mathrm{C}$ kemudian dimasukkan kedalam gelas yang telah steril. Sari buah sirsak diukur sebanyak 0\%, 15\%, 20\% dan $25 \%$ dari $50 \mathrm{ml}$ susu sapi yang dimasukkan ke wadah gelas steril, lalu dihomogenkan. Starter bakteri yoghurt diinokulasikan sebanyak 3\% dari $50 \mathrm{ml}$ susu kedalam gelas yang telah berisi susu pasteurisasi dan sari buah sirsak. Kemudian ditutup rapat dan diinkubasikan pada suhu $37^{\circ} \mathrm{C}$ selama 12 jam.

\section{Pengujian pH}

Pengukuran $\mathrm{pH}$ dilakukan dengan menggunakan $\mathrm{pH}$ meter. Alat $\mathrm{pH}$ meter dikalibrasi terlebih dahulu dengan buffer untuk $\mathrm{pH} 4$ dan $\mathrm{pH} 7$ sesuai kisaran $\mathrm{pH}$ yoghurt. Pengukuran $\mathrm{pH}$ yoghurt dilakukan dengan mencelupkan elektroda $\mathrm{pH}$ meter kedalam $10 \mathrm{ml}$ sampel yoghurt. 


\section{Pengujian total BAL}

Pengukuran total bakteri asam laktat dilakukan dengan menggunakan metode hitungan cawan (Total Plate Count). Metode yang digunakan yaitu dari pengenceran $10^{-9}$, sampel diambil sebanyak $1 \mathrm{ml}$ ke dalam cawan petri menggunakan pipet $1 \mathrm{ml}$. Kemudian medium MRS agar steril yang telah didinginkan sampai suhu $50^{\circ} \mathrm{C}$ dimasukkan ke dalam cawan tersebut sebanyak 10 $\mathrm{mL}$. Segera setelah penuangan, cawan petri digerakkan di atas meja secara hati-hati untuk menyebarkan sel-sel bakteri asam laktat secara merata, yaitu digerakkan melingkar atau gerakan seperti angka 8. Setelah agar memadat, cawan-cawan tersebut diinkubasi di dalam inkubator dengan posisi terbalik pada suhu $37^{\circ} \mathrm{C}$ selama 48 jam. Kemudian dilakukan penghitungan jumlah mikroba (CFU/ml) dengan colony counter (Fardiaz, 1993).

\section{Pengujian antibakteri}

Uji aktivitas antibakteri pada penelitian ini menggunakan metode sumuran. Bakteri uji yang digunakan pada penelitian ini yaitu Escherichia coli dan Shigella dysenteriae. Sebanyak $20 \mu \mathrm{L}$ suspensi bakteri uji dimasukkan ke dalam cawan petri. Dimasukkan medium NA sebanyak $20 \mathrm{~mL}$, dihomogenkan dengan cara menggerakkan cawan petri membentuk angka 8. Setelah padat, dibuat lubang sumuran dengan menggunakan pencadang besi sebanyak enam lubang pada masing-masing cawan petri. Kemudian dimasukkan sampel ke dalam lubang sumuran sebanyak $50 \mu \mathrm{L}$. Diinkubasi selama 24 pada suhu $37^{\circ} \mathrm{C}$, kemudian diukur diameter zona bening disekitar lubang sumuran.

\section{HASIL DAN PEMBAHASAN}

\section{Analisis pH yoghurt sari buah sirsak}

$\mathrm{pH}$ Yoghurt sari buah sirsak konsentrasi $0 \%, 15 \%, 20 \%, 25 \%, 50 \%$, dan 75\% dapat dilihat pada Tabel 1. Berdasarkan hasil pengukuran $\mathrm{pH}$ yoghurt, dapat dilihat bahwa semakin meningkat konsentrasi sari buah, semakin menurun nilai $\mathrm{pH}$. Penurunan $\mathrm{pH}$ disebabkan karena hasil fermentasi BAL yang mengubah gula-gula sederhana menjadi asam-asam organik, terutama asam laktat. Selain itu, penurunan pH juga disebabkan karena adanya asam-asam organik yang berasal dari sari buah 
sirsak, yaitu asam sitrat dan asam malat. Menurut Kartikasari (2014), asam sitrat dapat dirombak oleh Lactobacillus yang mungkin terdapat pada buah, begitu juga dengan asam malat.Akan tetapi, pada konsentrasi $75 \%$, terjadi peningkatan nilai $\mathrm{pH}$. Hal ini disebabkan karena pada konsentrasi $75 \%$, jumlah susu yang digunakan lebih sedikit sehingga asam laktat yang dihasilkan lebih sedikit. Semakin tinggi laktosa, maka semakin rendah nilai $\mathrm{pH}$ yoghurt. Menurut Food Standards Australia New Zealand (2014) pH yoghurt yang baik memiliki nilai maksimum 4,5. Sedangkan rentang $\mathrm{pH}$ yang diperoleh pada penelitian ini berkisar antara 4-5.

\section{Analisis total BAL yoghurt sari buah sirsak}

Menurut Standar Nasional Indonesia (SNI) 2981:2009, jumlah minimal total BAL dalam yoghurt tanpa perlakuan panas setelah fermentasi sebesar $10^{7} \mathrm{CFU} / \mathrm{ml}$. Berdasarkan hasil penelitian, yoghurt sari buah sirsak konsentrasi $0 \%, 15 \%, 20 \%$, $25 \%, 50 \%$, dan $75 \%$ memiliki total BAL sekitar $10^{9}$, yaitu lebih dari nilai minimal standar total BAL menurut SNI. Semakin tinggi konsentrasi sari buah sirsak semakin tinggi jumlah total BAL. Akan tetapi, pada konsentrasi $50 \%$ hingga $75 \%$ total BAL mengalami penurunan. Total BAL tertinggi diperoleh pada yoghurt dengan konsentrasi $25 \%$. Nilai Total BAL dapat dilihat pada Tabel 1.

Tabel 1. Nilai pH dan Total BAL Yoghurt Sari Buah Sirsak

\section{Analisis aktivitas antibakteri yoghurt sari buah sirsak}

Pengujian aktivitas antibakteri yoghurt sari buah sirsak dilakukan dengan menggunakan 5 variasi konsentrasi yaitu $0 \%, 15 \%, 20 \%, 25 \%, 50 \%$, dan $75 \%$ dengan bakteri uji Escherichia coli dan Shigella dysenteriae. Hasil uji antibakteri yoghurt sari buah sirsak dapat dilihat pada Gambar 1.

\begin{tabular}{|c|c|c|c|}
\hline Konsentrasi (\%) & $\begin{array}{c}\text { Waktu } \\
\text { fermentasi }\end{array}$ & pH & $\begin{array}{c}\text { Total BAL } \\
(\mathbf{c f u} / \mathrm{ml})\end{array}$ \\
\hline 0 & \multirow{6}{*}{12 jam } & 5,17 & $38 \times 10^{9}$ \\
\hline 15 & & 4,99 & $10 \times 10^{9}$ \\
\hline 20 & & 4,48 & $18 \times 10^{9}$ \\
\hline 25 & & 4,43 & $45 \times 10^{9}$ \\
\hline 50 & & 4,41 & $22 \times 10^{9}$ \\
\hline 75 & & 4,82 & $17 \times 10^{9}$ \\
\hline
\end{tabular}




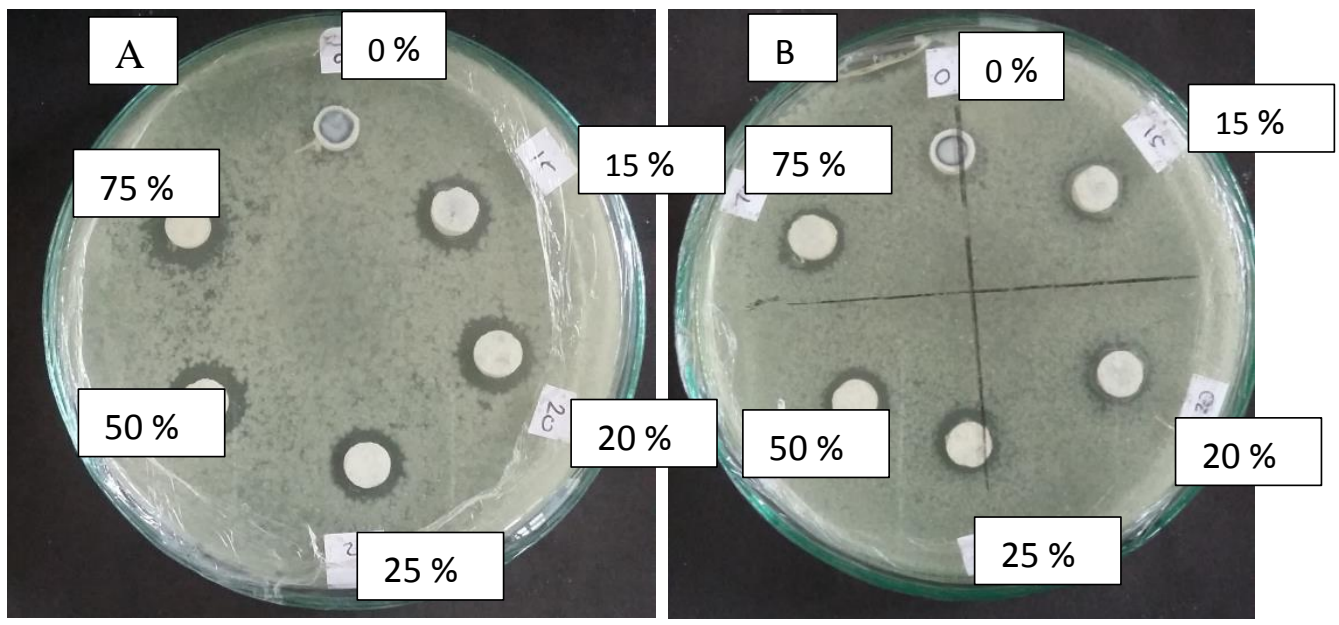

Gambar 1. (A) diameter zona bening yoghurt sari buah sirsak terhadap bakteri Escherichia coli, (B) Diameter zona bening yoghurt sari buah sirsak terhadap bakteri Shigella dysenteriae.

Berdasarkan hasil pengujian antibakteri yoghurt sari buah sirsak, yoghurt sari buah sirsak memiliki aktivitas antibakteri terhadap bakteri Escherichia coli dan Shigella dysenteriae. Hal ini ditandai dengan terbentuknya zona bening di sekitar lubang sumuran pada yoghurt konsentrasi $15 \%, 20 \%, 25 \%$, $50 \%$, dan $75 \%$. Semakin tinggi konsentrasi sari buah sirsak, semakin luas diameter zona bening yang terbentuk. Pada konsentrasi $75 \%$, terjadi penurunan aktivitas antibakteri terhadap bakteri Shigella dysenteriae. Hasil zona bening setiap konsentrasi dan setiap bakteri dapat dilihat pada Tabel 2.

Tabel 2. Diameter Zona Bening Yoghurt Sari Buah Sirsak

\begin{tabular}{ccc}
\hline \multirow{2}{*}{ Bakteri Uji } & Konsentrasi (\%) & $\begin{array}{c}\text { Rerata Diameter Zona } \\
\text { Bunuh (mm) }\end{array}$ \\
\hline \multirow{3}{*}{ Escherichia coli } & 0 & 0 \\
\cline { 2 - 3 } & 15 & 5,51 \\
\cline { 2 - 3 } & 20 & 6,63 \\
\cline { 2 - 3 } & 25 & 7,23 \\
\hline \multirow{3}{*}{ Shigella dysenteriae } & 50 & 7,64 \\
\cline { 2 - 3 } & 75 & 7,16 \\
\cline { 2 - 3 } & 0 & 0,00 \\
\cline { 2 - 3 } & 15 & 4,05 \\
\cline { 2 - 3 } & 20 & 4,56 \\
\cline { 2 - 3 } & 25 & 4,74 \\
\hline
\end{tabular}




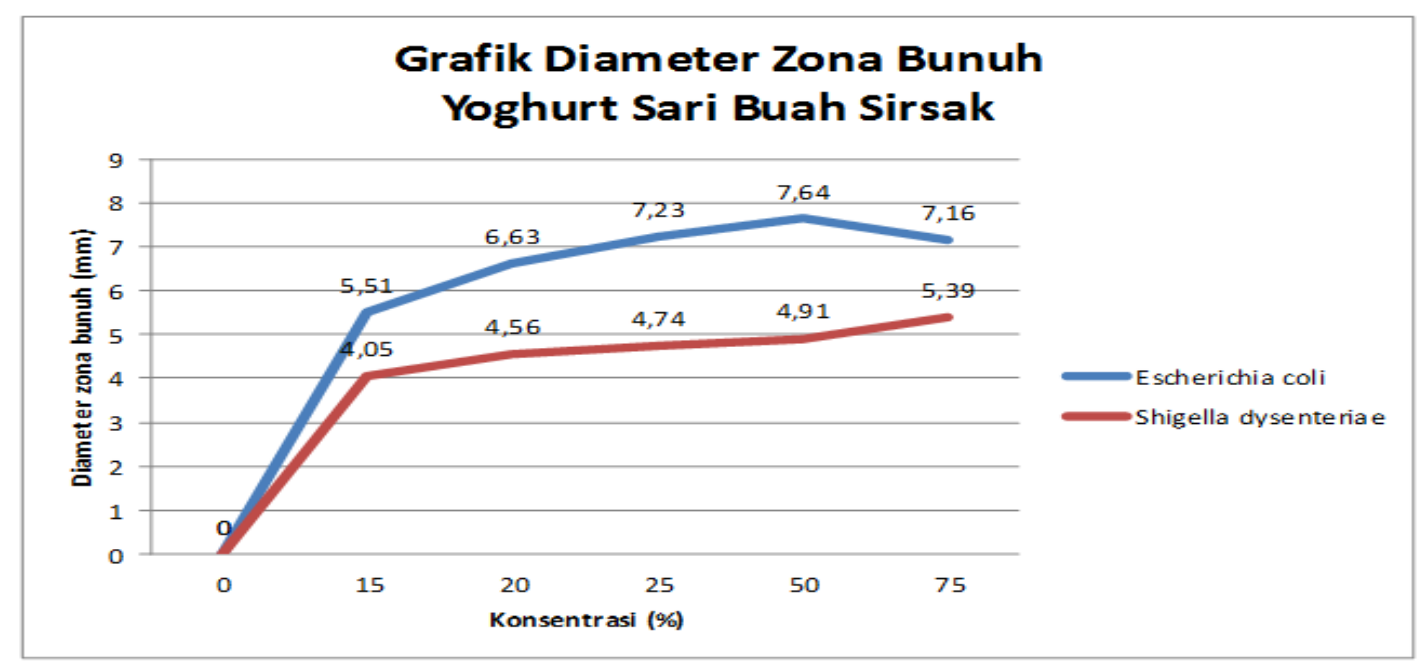

Gambar 2. Grafik Diameter Zona Bunuh Yoghurt Sari Buah Sirsak Terhadap Bakteri Escherichia coli dan Shigella dysenteria

\section{KESIMPULAN}

Berdasarkan penelitian yang telah dilakukan dapat diperoleh kesimpulan yaitu :

1. Yoghurt sari buah sirsak memiliki pH antara 4-5 dan beraktivitas antibakteri terhadap bakteri Escherichia coli dan Shigella dysenteriae.

2. Yoghurt dengan konsentrasi $50 \%$ memiliki aktivitas antibakteri terbaik terhadap bakteri Escherichia coli, dan yoghurt dengan konsentrasi $75 \%$ memiliki aktivitas antibakteri terbaik terhadap bakteri Shigella dysenteriae.

3. Berdasarkan total BAL, $\mathrm{pH}$ dan aktivitas antibakteri, yoghurt dengan penambahan sari buah sirsak yang paling baik adalah pada konsentrasi $25 \%$.

\section{DAFTAR PUSTAKA}

Octavia, mardiana, kartikasari, fardiaz, FDA, SNI

Badan Standar Nasional. 2009. SNI 2981:2009 Yogurt.

Fardiaz, S. 1993. Analisis Mirobiologi Pangan. Raja Grafindo Persada, Jakarta.

Food Standards Australia New Zealand. 2014. Standard 2.5.3 Fermented milk products

Kartikasari, Dian Izmi dan Fithri Choirun Nisa. 2014. Pengaruh Penambahan Sari Buah Sirsak dan Lama Fermentasi Terhadap Karakteristik Fisik dan Kimia Yoghurt. Jurnal Pangan dan Agroindustri vol 2 No. 4 p.239-248. 
Mardiana, Lina. 2012. Ramuan dan Khasiat Sirsak. Penebar Swadaya; Jakarta.

Octavia, Leni. 2003. Uji Antibakteri, Penentuan Kadar Vitamin C, dan Gula Total pada Buah Sirsak (Annona muricata L.). Skripsi. Bogor : Jurusan Kimia. Fakultas Matematika dan Ilmu Pengetahuan Alam. IPB. 